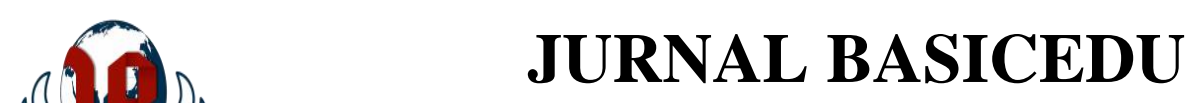

Volume 5 Nomor 5 Tahun 2021 Halaman 3001 - 3009

Research \& Learning in Elementary Education

https://jbasic.org/index.php/basicedu

PAVERSTTAS

\title{
Pengaruh Penerapan Model Pembelajaran Picture and Picture Berbantu Media Audio Visual terhadap Hasil Belajar di Sekolah Dasar
}

\author{
Fithrotul Ummah $^{1 凶}$, Dewi Widiana Rahayu ${ }^{2}$, Pance Mariati $^{3}$, Akhwani $^{4}$ \\ Pendidikan Guru Sekolah Dasar, Universitas Nahdlatul Ulama Surabaya, Indonesia ${ }^{1,2,3,4}$ \\ E-mail: fithrotulummah093.sd17@ student.unusa.ac.id $^{1}$, dewiwidiana@ unusa.ac.id² \\ Pance_mariati@unusa.ac.id ${ }^{3}$, akhwani@unusa.ac.id $^{4}$
}

\begin{abstract}
Abstrak
Penelitian ini bertujuan untuk mengetahui hasil belajar peserta didik menggunakan model pembelajaran Picture and Picture berbantu media audio visual. Tujuan dari penelitian ini adalah untuk mengetahui apakah ada pengaruh model pembelajaran Picture and Picture berbantu media audio visual terhadap hasil belajar peserta didik. Penelitian ini menggunakan quasi experiment dengan nonequivalent group design. Populasi dalam penelitian ini merupakan seluruh peserta didik kelas II SDN 266 Gresik berjumlah 14 peserta didik sedangkan Populasi dalam penelitian ini merupakan seluruh peserta didik kelas II SDN 262 Gresik berjumlah 11 peserta didik. Pengambilan sampel menggunakan teknik Purposive Sampling dan pengumpulan data menggunakan dokumentasi dan tes preetest posttest. Adapun uji data dianalisis menggunakan uji kolmogrov Smirnov, dari data hasil belajar peserta didik berdistribusi normal dan homogen diuji menggunakan uji $t$-test. Terdapat perbedaan hasil belajar peserta didik di kelas II SDN 266 Gresik yang menggunakan hasil belajar peserta didik pada kelas II SDN 266 Gresik yang menggunakan model Pembelajaran Picture and Picture berbantu Media Audio Visual dengan Kelas II SDN 262 Gresik yang menggunakan hasil belajar peserta didik pada kelas II SDN 266 Gresik yang menggunakan model Pembelajaran Picture and Picture berbantu Media Audio Visual dengan taraf signifikan $0.00<0.05$.
\end{abstract}

Kata Kunci: Hasil Belajar, Model Pembelajaran Picture and Picture Berbantu Media Audio Visual.

\begin{abstract}
This study aims to determine the learning outcomes of students using the Picture and Picture Learning model assisted by Audio Visual Media. The purpose of this study was to determine whether there was an effect of Picture and Picture Learning model assisted by Audio Visual Media on student learning outcomes. This study uses a quasi-experimental with a nonequivalent group design. The population in this study were all students of class II SDN 266 Gresik totaling 14 students while the population in this study were all class II students of SDN 262 Gresik totaling 11 students. Sampling using purposive sampling technique and data collection using documentation and pretest posttest. The test data were analyzed using the Kolmogrov Smirnov test, from the student learning outcomes data that were normally distributed and homogeneous were tested using the $t$-test. There are differences in student learning outcomes in class II SDN 266 Gresik who use student learning outcomes in class II SDN 266 Gresik using Picture and Picture Learning models assisted by Audio Visual Media with Class II SDN 262 Gresik using student learning outcomes in class II SDN 266 Gresik using Picture and Picture Learning model assisted by Audio Visual Media with a significant level of $0.00<0.05$.

Keywords: Learning Outcomes, Picture and Picture Learning Model Assisted by Audio Visual Media.
\end{abstract}

Copyright (c) 2021 Fithrotul Ummah, Dewi Widiana Rahayu, Pance Mariati, Akhwani

Corresponding author :

Email : fithrotulummah093.sd17@student.unusa.ac.id

DOI $\quad:$ https://doi.org/10.31004/basicedu.v5i5.1215

ISSN 2580-3735 (Media Cetak)

ISSN 2580-1147 (Media Online)

Jurnal Basicedu Vol 5 No 5 Tahun 2021

p-ISSN 2580-3735 e-ISSN 2580-1147 
3002 Pengaruh Penerapan Model Pembelajaran Picture And Picture Berbantu Media Audio Visual terhadap Hasil Belajar di Sekolah Dasar - Fithrotul Ummah, Dewi Widiana Rahayu, Pance Mariati, Akhwani

DOI : https://doi.org/10.31004/basicedu.v5i5.1215

\section{PENDAHULUAN}

Pendidikan merupakan wadah bagi peserta didik untuk mengembangkan potensinya. Potensi yang diharapkan yaitu adanya perubahan yang signifikan dalam diri siswa, termasuk kemampuan, kecerdasan, keterampilan, dan akhlak yang baik. Undang-undang No.20 Tahun 2003 tentang Sistem Pendidikan Nasional pasal pasal 1 (1) menjelaskan bahwa "Pendidikan adalah usaha sadar dan terencana untuk mewujudkan suasana belajar dan proses pembelajaran agar peserta didik secara aktif mengembangkan potensi dirinya untuk memiliki kekuatan spiritual keagamaan, pengendalian diri, kepribadian, kecerdasan, akhlak mulia, serta keterampilan yang diperlukan dirinya, masyarakat, bangsa dan negara." (Undang-Undang Republik Indonesia Sistem Pendidikan Nasional, 2003). Peserta didik membutuhkan sebuah dorongan untuk mengembangkan kemampuan yanga ada dalam dirinya. Guru merupakan seseorang yang berperan mendorong siswa untuk berperan aktif dalam pembelajaran.

Guru, peserta didik, dan model pembelajaran merupakan komponen utama yang saling berkaitan dalam proses belajar mengajar. Keberhasilan proses belajar mengajar sangat dipengaruhi oleh komponen-komponen tersebut, sehingga akan mempengaruhi hasil belajar peserta didik. Tetapi bisa juga dipengaruhi oleh faktorfaktor yang lain misalnya layanan dalam pembelajaran, motivasi belajar, sarana yang mendukung, infrastruktur yang baik, media pembelajaran dan sebagainya (Hapsari, 2019).

Keaktifan dan kreativitas dalam proses pembelajaran merupakan hal yang harus ada dalam diri guru dan peserta didik. Apabila guru aktif dan kreatif dalam menciptakan kegiatan pembelajaran maka suasana belajar akan lebih menarik dan menyenangkan. Begitu juga dengan peserta didik, jika peserta didik aktif dalam proses pembelajaran maka peserta didik akan lebih mudah memahami materi yang disampaikan dan hasil belajar tercapai sesuai dengan standar kompetensi. Oleh karena itu guru dan peserta didik yang aktif dalam proses belajar mengajar akan mendapatkan hasil yang maksimal dan sesuai dengan tujuan yang diharapakan. Seseorang dikatakan sudah belajar apabila dala dirinya terdapat perubahan pada perilakunya (Fauziah, 2017).

Dalam masa darurat Coronavirus Disease (Covid-19) merupakan suatu tantangan dalam bidang pendidikan maupun sektor lain yang harus dihadapi. Dalam suatu bidang pendidikan merupakan pemegang peran penting untuk menumbuhkan potensi sumber daya manusia melalui belajar mengajar. Dengan adanya pandemi covid-19, terjadilah perubahan dalam kegiatan belajar mengajar. Perubahan kegiatan tersebut berupa pelaksanaan belajar yang dilakukan di rumah masing-masing. Untuk memutuskan mata rantai penyebaran covid-19, maka pembelajaran tidak boleh dilaksanakan dengan cara tatap muka melainkan pembelajaran dalam jaringan (daring). Pembelajaran daring dilakukan disesuaikan dengan kemampuan masing-masing sekolah. Belajar daring dalam penelitian di SDN 266 Gresik dilakukan dengan menggunakan teknologi melalui whatsapp grup. Sehingga guru memiliki tantangan baru untuk melaksanakan pendidikan yang lebih menarik dan tidak monoton (Dewi, Wahyu Aji Fatma, 2020).

Pembelajaran daring merupakan aktivitas pembelajaran yang dilakukan melalui jaringan internet, atau berbagai macam aplikasi virtual yang sudah tersedia. Media yang sering digunakan dalam pembelajaran daring merupakan jaringan smartphone dan komputer. Adanya pembelajaran daring bukan berarti segala sistem pendidikan berjalan dengan sesuka hati, melainkan harus mengikuti aturan dan standar kompetensi yang ada. Perencanaan, pelaksanaa, dan evaluasi harus tetap ada dalam pembelajaran berbasis daring (Syarifudin, Albitar Septian, 2020). Jadi pembelajaran daring bukan sekedar berpindahnya materi melalui media internet, bukan juga tentang tugas tulis yang dikirim melalui link. Tetapi adanya peran guru yang nyata sebagaimana saat pembelajaran di kelas.

Dilihat dari penelitian-penelitian yang dilakukan peneliti terdahulu salah satu permasalahan yang sering ditemukan di lembaga pendidikan merupakan kurangnya guru dalam menyajikan model pembelajaran yang tepat (Hermawan, 2012). Model pembelajaran dan media pembelajaran sangat mempengaruhi aktivitas dan 
3003 Pengaruh Penerapan Model Pembelajaran Picture And Picture Berbantu Media Audio Visual terhadap Hasil Belajar di Sekolah Dasar - Fithrotul Ummah, Dewi Widiana Rahayu, Pance Mariati, Akhwani

DOI : https://doi.org/10.31004/basicedu.v5i5.1215

respon peserta didik. Model pembelajaran juga sangat membantu guru dalam menyampaikan materi pembelajaran, pemilihan model dan media pembelajaran yang tepat akan membuat peserta didik lebih bersemangat, aktif, tidak mudah bosan, dan hasil belajar siswa akan meningkat.

Berdasarkan penelitian Gede Risa Pebriana, dkk (2017: 9), penerapan model pembelajaran Picture and Picture dalam pembelajaran IPA dapat meningkatkan aktivitas dan hasil belajar peserta didik dengan persentase rata-rata aktivitas belajar peserta didik pertemuan I dan pertemuan II adalah $86,11 \%$ berada pada kategori aktif, persentase rata-rata hasil belajar peserta didik pada siklus II adalah $87,11 \%$ berada pada kategori tinggi (Pebriana \& Dibia, 2017).

Berdasarkan wawancara dengan guru kelas II di SDN 266 Gresik pada tanggal 19 November 2020, bahwa nilai peserta didik pada mata pelajaran PPKn pada materi perbedaan individu di sekolah berdasarkan suku atau asal daerahnya, masih sedikit siswa yang nilainya mencapai KKM. Nilai KKM pada mata pelajaran tersebut adalah 70, dari 14 peserta didik kelas II hanya 5 peserta didik yang mencapai KKM, sedangkan 9 peserta didik lainnya belum mencapai KKM.

Dari permasalahan tersebut salah satu model pembelajaran yang peneliti pilih untuk mengatasi permasalahan tersebut adalah model pembelajaran picture and picture, sedangkan media yang peneliti kombinasikan dengan model pembelajaran picture and picture adalah media audio visual, model pembelajaran yang menggunakan kumpulan gambar yang dijadikan sebuah video dengan diberikan beberapa penjelasan melalui audio visual agar peserta didik lebih mudah memahami materi yang diajarkan dan peserta didik lebih bersemangat karena proses pembelajaran lebih menarik.

Model pembelajaran merupakan rancangan untuk menyajikan materi ajar yang meliputi segala aspek pembelajaran yang akan dilaksanakan oleh guru pada saat proses pembelajaran, agar tercapainya tujuan pembelajaran yang diinginkan dan mempunyai fungsi sebagai pedoman untuk merencanakan dan melaksanakan aktivitas belajar mengajar peserta didik ( elvina, 2019, 13).

Pengertian model pemebelajaran picture and picture merupakan model pembelajaran menggunakan gambar, jadi guru harus menyiapkan media gambar yang menjadi media utama dalam pembelajaran ini. Model pembelajaran Picture and Picture merupakan model pembelajaran yang menggunakan media gambar (Haryoko, Sapto, 2009). Sedangkan Media audio visual merupakan media antara audio dan visual. Media audio visual juga dapat diartikan sebagai media yang mempunyai dua unsur, yaitu unsur suara dan unsur gambar seperti slide, video dan sebagainya. Menurut Andersoon (1994) proses pembelajaran menggunakan media audio visual menjadikan lebih menarik perhatian peserta didik dalam menyampaikan materi ajar dan pembelajaran tidak membosankan.

Langkah-langkah pembelajaran menggunakan picture and picture, pertama guru memberikan kompetensi yang ingin dicapai, selanjutnya guru menyiapkan materi untuk pengantar pembelajaran, guru menunjukan gambar yang berkaitan dengan materi pembelajaran, guru menunjuk peserta didik bergantian untuk mempresentasikan gambar-gambar menjadi urutan benar, guru menanyakan alasan urutan gambar tersebut, dan yang terakhir guru menanamkan materi sesuai dengan kompetensi yang ingin dicapai (Uchi, 2018).

penelitian ini menggunakan langkah-langkah dalam video sebagai berikut agar peserta didik lebih memahami apa yang sudah disampaikan dalam video:

1) Guru membuka pelajaran dengan salam, menanyakan kabar dan mengecek kehadiran siswa secara online melalui WhatsApp Group, lalu berdo'a.

2) Siswa diminta untuk mengerjakan soal pretest yang diadakannya pada hari sebelum diberikan video pembelajaran secara online.

3) Guru menyampaikan kompetensi dasar (KD), dan tujuan pembelajaran tentang tema 3 subtema 2 pembelajaran 4 . 
3004 Pengaruh Penerapan Model Pembelajaran Picture And Picture Berbantu Media Audio Visual terhadap Hasil Belajar di Sekolah Dasar - Fithrotul Ummah, Dewi Widiana Rahayu, Pance Mariati, Akhwani

DOI : https://doi.org/10.31004/basicedu.v5i5.1215

4) Siswa mengamati dan memahami media video tentang mengidentifikasi jenis-jenis keberagaman karakteristik individu di sekolah, melalui vidio yang dishare di group WA

5) Guru memberikan kesempatan kepada siswa untuk bertanya tentang mengidentifikasi jenis-jenis keberagaman karakteristik individu di sekolah yang sudah dijelaskan di dalam video yang sudah di share di WhatsApp Group.

6) Guru menjawab pertanyaan-pertanyaan siswa yang ada di WhatsApp Group.

7) Peserta didik diminta untuk menyimpulkan penjelasan yang sudah diberikan.

8) Siswa diminta untuk mengerjakan soal posttest yang diadakannya setelah diberikan video pembelajaran secara online.

9) Guru menutup pembelajaran dengan doa dan salam.

Kelebihan model pembelajaran picture and picture, yang pertama peserta didik dengan mudah menangkap, memahami materi yang diajarkan karena guru menunjukan media gambar-gambar, yang kedua materi diajarkan lebih tersusun dengan baik karena pada awal proses pembelajaran materi yang dijelaskan lebih singkat terlebih dahulu dan mejelaskan kompetensi yang akan dicapai, yang ketiga daya pikir atau daya nalar peserta didik dapat meningkat karena peserta didik menganalisa gambar yang sudah disediakan, yang keempat tanggung jawab jawab peserta didik lebih meningkat, sebab guru menanyakan alasan peserta didik mengurutkan gambar yang sudah tersedia, yang terakhir pembelajaran lebih berkesan, karena peserta didik secara langsung dapat mengamati gambar yang sudah tersedia (Musrifah, 2020).

Media audio visual merupakan media pendidikan dan media pengajaran yang menjadikan mata dan telinga peserta didik aktif dalam waktu bersamaan dalam proses pembelajaran berlangsung (Haryoko, Sapto, 2009). Kombinasi antara model pembelajaran picture and picture berbantu media audio visual merupakan solusi yang dapat digunakan dalam pembelajaran PPKn pada materi mengetahui keberagaman karakteristik individu di sekolah, karena akan membuat peserta didik lebih tertarik untuk belajar karena pembelajarannya menggunakan gambar-gambar dan video. Hasil belajar merupakan kegiatan pembelajaran yang dapat mengubah kemampuan seseorang, yang dimaksudkan dalam hasil belajar merupakan hasil belajar kognitif yaitu perubahan kecerdasan peserta didik yang diperoleh sesudah mendapatkan penerapan dari model pembelajaran yang digunakan. Hasil belajar juga mempunyai artian perubahan tingkah laku individu dan individu dengan ligkugannya. Perubahan tingkah laku seseorang akan mengalami perubahan setelah melakukan proses belajar mengajar, baik perubahan pengetahuan (kognitif), keterampilannya maupun perubahan sikap (Prayudi, 2017).

\section{METODE PENELITIAN}

Sesuatu penelitian membutuhkan metode pengumpulan informasi yang cocok untuk sesuai suatu tujuan yang hendak dicapai. Jenis penelitian yang digunakan dalam penelitian ini adalah penelitian eksperimen, metode eksperimen merupakan metode yang digunakan untuk mengetahui pengaruh variabel independen (treatment) terhadap variabel dependen (hasil) (sugiyono, 2017:111). Rancangan dalam penelitian memakai penelitian adalah Quasi Experimental Design. Ada pula wujud desain Quasi Experimen yang digunakan merupakan desain nonequivalent control group design, ialah desain quasi experiment yang memandang perbedaan pretest ataupun posttest. Tujuan penelitian ini merupakan untuk mengetahui ada tidaknya pengaruh tersebut dengan cara memberikan perlakuan model pembelajaran picture and picture pada kelas eksperimen dan menyediakan kelas kontrol. Pembelajaran pada kelas eksperimen mendapatkan perlakuan dengan proses pembelajaran menggunakan model picture and picture sedangkan pembelajaran pada kelas kontrol menggunakan model pembelajaran konvesional. Pembelajaran Konvesional merupakan pembelajaran tradisional yang kadang disebut juga dengan pembelajaran ceramah, karena sejak dulu pembelajaran ini 
3005 Pengaruh Penerapan Model Pembelajaran Picture And Picture Berbantu Media Audio Visual terhadap Hasil Belajar di Sekolah Dasar - Fithrotul Ummah, Dewi Widiana Rahayu, Pance Mariati, Akhwani

DOI : https://doi.org/10.31004/basicedu.v5i5.1215

digunakan sebagai alat komunikasi secara lisan antara guru dengan peserta didik pada saat proses pembelajaran berlangsung (Syahdani, 2014). Pada akhir pertemuan peserta didik diberi posttest dengan memberikan tes kemampuan penyelesaian soal dalam bentuk pilihan ganda yang dilakukan pada kedua kelas sampel dengan tes soal yang sama untuk mengetahui hasil belajar peserta didik (Putri, Maya, 2016 :30). Pengambilan data awal dilaksanakan pada tanggal 9-28 bulan November 2020 saat terlaksananya Program Praktik Pengalaman Lapangan, dan pengambilan data kedua dilaksanakan pada semester genap pada tanggal 3-5 Juni 2021. Populasi merupakan sesuatu golongan yang di dalamnya terdapat objek ataupun subjek yang mempunyai ciri yang ditetapkan oleh peneliti untuk lebih dipelajari dan ditarik kesimpulannya (sugiyono, 2018:130). Pelaksanaan penelitian ini dilakukan didua sekolah dikarenakan dalam penelitian di SDN 266 Gresik, Kelurahan Racitengah, Kecamatan Sidayu, Kabupaten Gresik dan di SDN 266 Gresik, Kelurahan Lasem, Kecamatan Sidayu, Kabupaten Gresik. Populasi dalam penelitian ini merupakan seluruh peserta didik kelas II SDN 266 Gresik berjumlah 14 peserta didik, dan SDN 262 Gesik berjumlah 11 peserta didik. Jumlah dan karakteristik yang ada pada populasi disebut dengan sampel. Jumlah dan karakteristik yang ada pada populasi disebut dengan sampel. Pengambilan sampel pada penelitian ini menggunakan teknik Purposive Sampling dikarenakan sampel pada penelitian ini ditentukan untuk persamaan karakteristik yang dimiliki dua sekolah seperti, akreditasi, kemampuan peserta didik, dan lingkungan sekolah (Thirsa Laules Purwa, Hendratno, 2019: 2813). Pengambilan sampel pada penelitian ini menggunakan teknik Purposive Sampling dikarenakan sampel pada penelitian ini ditentukan untuk persamaan karakteristik yang dimiliki dua sekolah seperti, akreditasi, kemampuan peserta didik, dan lingkungan sekolah. Teknik pengumpulan data dalam penelitian ini menggunakan dokumentasi dan tes preetest posttest. Dokumentasi merupakan catatan peristiwa pada waktu yang lalu, dan dapat berbentuk tulisan, gambar, maupun karya-karya monumental dari seseorang(Febrian Rissa , 2021), sedangakan Tes merupakan upaya pengukuran yang sudah terencana yang digunakan oleh guru untuk memberikan kesempatan kepada peserta didik dalam memperlihatkan prestasi mereka yang berkaitan dengan tujuan yang telah ditentukan (Wulan, 2007). Uji Normalitas bertujuan untuk mengetahui informasi dari kedua kelas yang berupa nilai hasil belajar dari populasi berdistribusi normal atau tidak. Teknik pengujian data ini menggunakan spss (Sugiyono, 2019:206). Uji normalitas menggunakan OneSampel Komlmogrov-smirnove Test, diketahui bahwa kelompok eksperimen mempunyai taraf signifikan sebesar 0,200 atau > dari 0,05 maka dapat dinyatakan bahwa data tersebut berdistribusi normal. Sedangkan kelompok kontrol mempunyai nilai signifikansi sebesar 0,055 atau > dari 0,05, maka dapat dinyatakan data tersebut berdistribusi normal. Uji Homogen diketahui nilai signifikansinya adalah sebesar 0,892>0,05 sehingga dapat disimpulkan bahwa varians data dari dua kelompok populasi data adalah homogen. Berdasarkan hasil uji normalitas dan homogenitas pada penelitian ini diperoleh data berdistribusi normal dan homogen. Peneliti menggunakan statistic parametric dikarenakan data normal dan homogen, adapun rumus yang digunakan adalah $t$-test. Uji hipotesis yang digunakan dalam penelitian ini adalah t-tes. Uji ini digunakan untuk mengetahui perbedaan antara hasil belajar peserta didik yang menggunakan model pembelajaran picture and picture berbantu media audio visual dan yang menggunakan model pembelajaran konvesional. Uji sampel t-test Kelas yang menggunakan model pembelajaran picture and picture berbantu media audio visual (SDN 266 Gresik) yaitu 87.14 lebih besar dari pada kelas yang tidak menggunakan model pembelajaran picture and picture berbantu media audio visual (SDN 262 Gresik) yaitu 66.36. Dengan demikian nilai pada kolom sig terlihat bahwa nilai probabilitas 0,000 maka $\mathrm{H}_{1}$ diterima $(0,000<0,05)$. Dengan demikian dapat disimpulkan bahwa ada perbedaan signifikan nilai hasil belajar peserta didik yang menggunakan model pembelajaran picture and picture berbantu media audio visual. 
3006 Pengaruh Penerapan Model Pembelajaran Picture And Picture Berbantu Media Audio Visual terhadap Hasil Belajar di Sekolah Dasar - Fithrotul Ummah, Dewi Widiana Rahayu, Pance Mariati, Akhwani

DOI : https://doi.org/10.31004/basicedu.v5i5.1215

\section{HASIL DAN PEMBAHASAN}

Berikut ini merupakan hasil nilai uji t untuk kelompok eksperimen setelah dilakukan treatment.

Tabel 1 One-Sample Statistics - Kelompok Eksperimen

\begin{tabular}{ccccc}
\hline \multicolumn{5}{c}{ One-Sample Statistics } \\
\hline & N & Mean & Std.Deviation & Std.Eror Mean \\
\hline Posttest & 14 & 87.14 & 9.139 & 2.442 \\
\hline
\end{tabular}

Tabel 2 One-Sample Test- kelompok Eksperimen

\begin{tabular}{ccccccc}
\hline \multicolumn{7}{c}{ One-Sample Test } \\
\hline & $\mathbf{t}$ & df & Sig. (2-tailed) & $\begin{array}{c}\text { Mean } \\
\text { Difference }\end{array}$ & $\begin{array}{c}\text { 95\% Confidence } \\
\text { Interval Of The } \\
\text { Difference }\end{array}$ \\
\cline { 3 - 7 } & & & & & Lower & Upper \\
\hline Posttest & 7.019 & 13 & .000 & 17.143 & 11.87 & 22.42 \\
\hline
\end{tabular}

Berdasarkan output kedua One Sample Test. Didapatkan nilai t-hitung sebesar 7.019 dengan derajat bebas $13(\mathrm{~N}-1)$ dengan nilai Sig (2-tiled) sebesar 0,000 < 0,05 artinya signifikan. Maka dari itu berdasarkan tabel di atas nilai pada kolom sig bahwa nilai probabilitas 0,000 maka $\mathrm{H}_{0}$ ditolak $(0,000<0,05)$ dan $\mathrm{H}_{1}$ diterima, sehingga dapat disimpulkan bahwa nilai rata-rata peserta didik kelas II SDN 266 Gresik yang menggunkan pembelajaran picture and picture berbantu media audio visual tidak sama dengan 70 . Nilai ratarata yang menggunakan pembelajaran picture and picture berbantu media audio visual adalah 87.,14.

Berikut ini adalah hasil nilai uji t untuk kelompok kontrol setelah dilakukan treatment.

Tabel 3 One-Sample Statistics - Kelompok Kontrol

\begin{tabular}{ccccc}
\hline \multicolumn{5}{c}{ One-Sample Statistics } \\
\hline & N & Mean & Std.Deviation & Std.Eror Mean \\
\hline Posttest & 11 & 66.36 & 11.201 & 3.377 \\
\hline
\end{tabular}

Tabel 4 One-Sample Test - Kelompok Kontrol

\begin{tabular}{ccccc}
\hline \multicolumn{5}{c}{ One-Sample Test } \\
\hline t & df & Sig. (2-tailed) & Mean \\
Difference & $\begin{array}{c}\text { 95\% Confidence } \\
\text { Interval Of The } \\
\text { Difference }\end{array}$ \\
\end{tabular}

\begin{tabular}{ccccccc} 
Posttest & -1.077 & 10 & .307 & -3.636 & -11.16 & Upwer \\
\hline
\end{tabular}

Bersarakan output yang kedua One Sample Test. Didapatkan nilai t-hitung sebesar -1.077 dengan derajat bebas $10(\mathrm{~N}-1)$ dengan nilai Sig (2-tailed) sebesar $0.307>0.05$ artinya tidak signifikan.

Dengan demikian dari hasil diatas nilai pada kolom sig terlihat bahwa nilai probabilitas 0,307 maka $\mathrm{H}_{0}$ diterima $(0,307>0,05)$ dan $\mathrm{H}_{1}$ ditolak. Sehingga dapat disimpulkan bahwa nilai rata-rata hasil belajar peserta didik di kelas II SDN 262 Gresik yang tidak menggunakan picture and picture berbantu media audio visual sama dengan 70 . Nilai rata-rata peserta didik yang menggunakan picture and picture berbantu media audio visual adalah 87,14.

Tabel 5 One-Sample Kolmogrov-Smirnov Test

\begin{tabular}{cc}
\hline \multicolumn{3}{c}{ One-Sample Kolmogrov-Smirnov Test } \\
\hline Kelompok Kontrol & Kelompok \\
& Eksperimen \\
\hline
\end{tabular}


3007 Pengaruh Penerapan Model Pembelajaran Picture And Picture Berbantu Media Audio Visual terhadap Hasil Belajar di Sekolah Dasar - Fithrotul Ummah, Dewi Widiana Rahayu, Pance Mariati, Akhwani

DOI : https://doi.org/10.31004/basicedu.v5i5.1215

\begin{tabular}{cccc}
\hline $\mathrm{N}$ & & 11 & 14 \\
\hline Normal & Mean & .0000000 & .0000000 \\
\cline { 2 - 4 } Parameters $^{\mathrm{a}, \mathrm{b}}$ & Std. Deviation & 7.5370548 & 8.75261381 \\
\hline Most Extreme & Absolute & .249 & .154 \\
\hline Difference & Positive & .206 & .094 \\
\cline { 2 - 4 } & Negative & -249 &. .154 \\
\hline Test Statistic & & .249 & .154 \\
\hline $\begin{array}{c}\text { Asymp. Sig. }(2- \\
\text { tailed) }\end{array}$ & & $.055^{\mathrm{c}}$ & $.200^{\mathrm{c}, \mathrm{d}}$ \\
\hline
\end{tabular}

a. Test distribution is Normal

b. Calculated from data

c. Liliefors Significance Correction

Berdasarkan tabel diatas dapat diketahui bahwa kelompok eksperimen mempunyai taraf signifikan sebesar 0,200 atau > dari 0,05 maka dapat dinyatakan bahwa data tersebut berdistribusi normal.

Tabel 6 Test of Homogenity of Variance

\begin{tabular}{cccc}
\hline \multicolumn{5}{c}{ Test of Homogenity of Variance } \\
\hline \multicolumn{4}{c}{ Posttest } \\
\hline Lavene Statistics & df1 & df2 & Sig. \\
\hline .019 & 1 & 21 & .892 \\
\hline
\end{tabular}

Beradasarkan tabel diatas dapat diketahui nilai signifikansinya adalah sebesar 0,892 >0,05 sehingga dapat disimpulkan bahwa varians data dari dua kelompok populasi data adalah homogen.

Tabel 7 One-Sample Statistic

\begin{tabular}{cccccc}
\hline \multicolumn{5}{c}{ One-Sample Statistic } \\
\hline Kelas & N & Mean & Std.Deviation & $\begin{array}{c}\text { Std.Eror } \\
\text { Mean }\end{array}$ \\
\hline Belajar & $\begin{array}{c}\text { SDN 266 } \\
\text { Gresik }\end{array}$ & 14 & 87.14 & 9.139 & 2.442 \\
\cline { 2 - 6 } & $\begin{array}{c}\text { SDN 262 } \\
\text { Gresik }\end{array}$ & 11 & 66.36 & 11.201 & 3.377 \\
\hline
\end{tabular}

Berdasarkan tabel diatas 4.12 menunjukan mean (rata-rata) tiap kelas. Kelas yang menggunakan model pembelajaran picture and picture berbantu media audio visual (SDN 266 Gresik) yaitu 87.14 lebih besar dari pada kelas yang tidak menggunakan model pembelajaran picture and picture berbantu media audio visual (SDN 262 Gresik) yaitu 66.36.

Tabel 8 Independent Sample Test

\section{Independent Sample Test}

\begin{tabular}{|c|c|c|c|c|}
\hline $\begin{array}{l}\text { Levene's } \\
\text { Test for } \\
\text { Equality of } \\
\text { Variances }\end{array}$ & & \multicolumn{3}{|c|}{ t-test of Equality of Means } \\
\hline f $\quad$ Sig. & $\mathrm{t} \quad \mathrm{df}$ & $\begin{array}{l}\text { Sig. } \\
\text { (2- } \\
\text { tailed) }\end{array}$ & $\begin{array}{c}\text { Mean } \\
\text { difference }\end{array}$ & $\begin{array}{l}\text { Std. Error } \\
\text { Difference }\end{array}$ \\
\hline
\end{tabular}

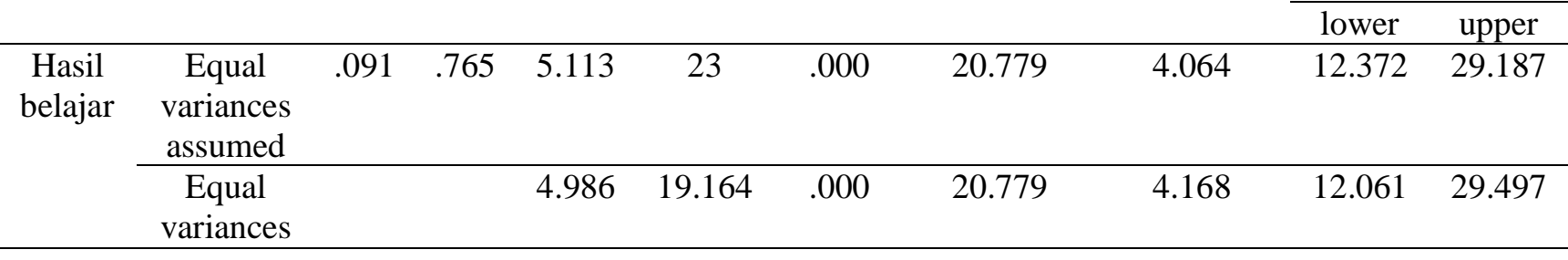


3008 Pengaruh Penerapan Model Pembelajaran Picture And Picture Berbantu Media Audio Visual terhadap Hasil Belajar di Sekolah Dasar - Fithrotul Ummah, Dewi Widiana Rahayu, Pance Mariati, Akhwani

DOI : https://doi.org/10.31004/basicedu.v5i5.1215

not

assumed

Dengan demikian dari hasil diatas nilai pada kolom sig terlihat bahwa nilai probabilitas $0,000 \mathrm{maka}_{1}$ diterima $(0,000<0,05)$. Dengan demikian dapat disimpulkan bahwa ada perbedaan signifikan nilai hasil belajar peserta didik yang menggunakan model pembelajaran picture and picture berbantu media audio visual.

\section{KESIMPULAN}

Hasil belajar peserta didik yang menggunakan model pembelajaran picture and picture berbantu media audio visual di kelas II SDN 266 Gresik dengan nilai rata-rata 87,14 dan sudah mencapai KKM yang sudah ditentukan yaitu 70.

Hasil belajar peserta didik yang tidak menggunakan model pembelajaran picture and picture berbantu media audio visual di kelas II SDN 262 Gresik dengan nilai rata-rata 66,36 dan sebagian sudah mencapai nilai yang sudah ditentukan yaitu 70 .

Ada perbedaan hasil belajar peserta didik di kelas II SDN 266 Gresik yang menggunakan model pembelajaran picture and picture berbantu media audio visual dengan kelas II SDN 262 Gresik yang tidak menggunakan model pembelajaran picture and picture berbantu media audio visual, yang dimana kelompok eksperimen berjumlah 14 peserta didik nilai rata-rata yang didapat 87,14 sedangkan kelompok kontrol berjumlah 11 peserta didik nilai rata-rata yang didapat 66,36. Berdasarkan hasil belajar peserta didik dari kedua keompok diatas meningkat sebesar 20,78\%.

\section{DAFTAR PUSTAKA}

Andri Hapsari. (2019). Keefektifan Model Pembelajaran Picture And Picture Terhadap Hasil Belajar Ips Siswa Kelas Iv Sdn Gugus Cendana Kecamatan Blora Kabupaten Blora. Skripsi. Semarang: UNNES.

Cut Yoesi Elvina. (2019). Penerapan Model Pembelajaran Picture And Picture Dan Media Audio Visual Terhadap Aktivitas Dan Hasil Belajar Siswa Pada Materi Sistem Gerak Manusia Di Smas Babul Maghfiroh Aceh Besar. Skripsi. Banda Aceh: Universitas Islam Negeri Ar-Raniry.

Dwi Handayani, N. M. Ganing, N. N. Suniasih, N. W. (2017). Model Pembelajaran Picture And Picture Berbantuan Media Audio-Visual Terhadap Kompetensi Pengetahuan Ipa. Journal Of Education Technology, 1(3), 176.

Fauziah. (2009). Upaya Meningkatkan Motivasi Belajar Siswa Melalui Lesson Studydi Kelas V Sd Negeri Lampagen Aceh Besar. Ilmiah Pendidikan Guru Sekolah Dasar, 2, 30-38.

Haryoko, Sapto. (2009). (N.D.). Efektivitas Pemanfaatan Media Audio Visual Sebagai Alternatif Optimalisasi Model Pembelajaran. Journal Article, 1-10.

Hermawan, A. (2012). Problematika Metode Pembelajaran Aktif Bagi Guru Pendidikan Agama Islam Di MI Nurul Ulum Sokokidul Kebonagung Demak. Skripsi. Semarang: Insitut Agama Islam Negeri Walisongo.

Musrifah, F. Ayu, Rahmah, A., \& Wahyuni, S. (2020). Metode Picture And Picture Dalam Meningkatkan Motivasi Belajar Bahasa Arab. Journal Article, 1, 15-26.

Pebriana, G. Risa, \& Dibia, I Ketut. (2017). Penerapan Model Pembelajaran Picture And Picture Untuk Meningkatkan Aktivitas Dan Hasil Bekajar Ipa Kelas V Universitas Pendidikan Ganesha. Journal Article, 1-10. 
3009 Pengaruh Penerapan Model Pembelajaran Picture And Picture Berbantu Media Audio Visual terhadap Hasil Belajar di Sekolah Dasar - Fithrotul Ummah, Dewi Widiana Rahayu, Pance Mariati, Akhwani

DOI : https://doi.org/10.31004/basicedu.v5i5.1215

Prayudi, Lalu M. Eka, Sahidu, H., \& Gunawan. (2017). Pengaruh Penggunaan Media Audiovisual Dengan Pendekatan Metakognitif Berbasis Masalah Terhadap Hasil Belajar Fisika Siswa Kelas XI IPA Di SMAN 1 Gerung Tahun Pelajaran 2016 / 2017. Journal Article, III(1).

Putri, Maya, 2016. (2016). Pengaruh Model Pembelajaran Kooperatif Tipe Picture And Picture Terhadap Hasil Belajar Ips Siswa Kelas IV SD Negeri I Rajabasa. 2016. Journal Article.

Sugiyono. (2019). Metode Penelitian Kuantitatif (Setiyawami, Ed.). Bandung : ALFABETA.

Sugiyono, 2017. (2017). Metode Penelitian Kuantitatif. Bandung: ALFABETA.

Sugiyono, 2018. (2018). Metode Penelitian Kuantitatif. Bandung: ALFABETA.

Syahdani, F. (2014). Perbandingan Hasil Belajar Siswa Menggunakan Model Pembelajaran Kooperatif Tipe Nht Dikombinasikan Dengan Model Pembelajaran Pbl Dengan Model Pembelajaran Konvensional Di Man 1 Model Kota Bengkulu. Skripsi. Bengkulu: Universitas Bengkulu.

Syarifudin, Albitar Septian. (2020). Impelementasi Pembelajaran Daring Untuk Meningkatkan Mutu Pendidikan Sebagai Dampak Diterapkannya Social Distancing. Jurnal Pendidikan Bahasa Dan Sastra Indonesia Metalingua, 5(1), 31-34.

Thirsa Laules Purwa, Hendratno. (2019). Pengaruh Media Wayang Kertas Terhadap Keterampilan Bercerita Siswa Kelas Iv Sdn Di Kecamatan Modo Lamongan. Journal PGSD, 2811-2820.

Uchi, A. Yana. (2018). Pengaruh Penggunaan Model Pembelajaran Kooperatif Tipe Picture And Picture Terhadap Hasil Belajar Siswa. Skripsi. Bandar Lampung: Universitas Lampung

Undang-Undang Republik Indonesia Sistem Pendidikan Nasional. (2003).

Wulan, A. R. (2007). Pengertian Dan Esensi Konsep Evaluasi, Asesmen, Tes, Dan Pegukuran. Jurnal FPMIPA Universitas Pendidikan Indonesia, 1-12. 